\title{
What about the Urban Periphery? The Effects of the Urban Renaissance in the Mersey Belt*
}

\author{
Sebastian Dembski, Andreas Schulze Bäing, Olivier Sykes
}

\begin{abstract}
Cities in the UK have undergone an urban renaissance since the late 1990s, when New Labour started an initiative of the same name. However, the effects of urban growth have been limited mainly to the cores of second-tier cities, creating new challenges in the urban fringe of city regions and for cities outside the major agglomerations. In this article, we examine the process of reurbanisation in the Manchester and Liverpool city regions and to take a closer look at on one of the local authorities in the fringe of these city regions which is trying to grapple with the challenges posed by a new urban age. We find increasing evidence that places in the spatial in-between of urban regions face particular challenges as a result of the urban renaissance, with the already problematic areas requiring increased attention to avoid structural urban problems similar to that of the inner urban areas in the past.
\end{abstract}

Keywords: Urban Renaissance · Reurbanisation · Urban Periphery · City Regions · Small and Medium Towns

\section{Introduction}

Certainly since the start of the new millennium, evidence has amassed that the economic resurgence of cities increasingly translates into demographic growth, even in those cities most heavily affected by the change towards post-industrial urban economies. This process is commonly referred to as reurbanisation. Already in the mid-2000s a major study in the UK suggested "bright demographic prospects for urban England, especially its larger cities" (Parkinson et al. 2006: Vol. 2, 111). This outlook was confirmed in the 2011 Census, showing that cities have indeed regained population over the previous decade, and in many cases substantially. More impor-

\footnotetext{
This article belongs to a special issue on reurbanisation.
} 
tantly, growth is not restricted to booming London and the wider Southeast, but has also reached second-tier cities. For instance, Manchester grew by almost 20 percent over the period 2001-2011 (Rae 2013). However, while all of Britain's large urban areas have gained population, not all of them have grown as strongly as the UK population (McCann 2016: 125). Similar evidence can be found for Germany, the Netherlands and Switzerland (Brake/Herfert 2012; Rérat 2012; Van Gent/Musterd 2016).

However, the literature has by and large focussed on the pronounced rebirth of the urban core; the suburban hinterland is mainly left out of the equation (Salet et al. 2015; Savini 2014). Many authors have pointed to the dark side of the urban renaissance, criticising its strong focus on the middle-class and offices (Porter/Shaw 2009). Whether such critique is fully-grounded in an appreciation of the longer-term trajectories of growth and decline of certain places (Shaw/Sykes 2015), and the achievement for public policy and investment that variants of the "urban renaissance" in different international contexts represent, is perhaps a moot point. Another feature of such "critical" literature is that, whilst it extensively explores such "social ills" as the proliferation of chain-owned coffee shops, city centre retail development, and "gentrification" of abandoned industrial areas, sites and buildings through the installation of new "profit-seeking" uses, it is largely silent on the wider transformation of the periphery of urban regions where most people live. Meanwhile, the literature on shrinking cities has been mainly concerned with the decline of urban regions as a result of deindustrialisation and suburbanisation (e.g. Wiechmann/Pallagst 2012; Couch et al. 2005) and more recently their re-growth (e.g. Rink et al. 2012), but only occasionally addresses the role of suburbs and small towns within urban areas (e.g. Albecker/Fol 2014; Audirac et al. 2012; Blanco et al. 2009). The periphery has been mainly considered from the perspective of urban sprawl (e.g. Siedentop/Fina 2012) and from discussing the role of peri-urban areas and the rural-urban fringe (e.g. Gallent et al. 2006; Hoggart 2005).

In this paper, we follow the plea of Soja (2015) to take a regional perspective on urban issues. So far, what is largely lacking from the parallel tracks of investigation outlined above, are accounts that reflect on how dynamic processes of change in urban cores and those in the "edge territories" of urban regions might be related and problematized. Taken together with the observed phenomenon of reurbanisation, we might wonder how reurbanisation effects play out. Put simply the questions might be: What happens with the urban periphery when growth is very strong in the centre? And what policy options do places in the periphery have in relation to reurbanisation?

The Mersey Belt, consisting of the Manchester and Liverpool city regions and adjacent areas, forms an excellent study ground to investigate the process mentioned above as both cities have regrown after decades of urban decline. Half of the population growth of Greater Manchester occurred within Manchester. Similarly, Liverpool was the main driver of population growth of the city region, mainly because the other local authorities had very low growth rates or even declining populations. We will review the policy responses of one of those towns in the spatial in-between of the Manchester and Liverpool city-regions, the former mining town of St. Helens. 
In the remainder of the article, we cast light on the changing periphery in urban regions over the past decades. We then concentrate on the Manchester and Liverpool city regions and the changes that have taken place since the turn of the millennium in terms of demographic, economic and social indicators. In the next section, we elaborate on the challenging situation of a local authority in the urban fringe and how it is trying to find its role in the context of two big neighbours. The paper calls for renewed attention to the role of the urban fringe in an urban age and reflects on the policy implications for places in the fringe.

\section{The changing relationship between centre and periphery in urban regions}

The second half of the twentieth century witnessed a fundamental restructuring of urban form, resulting in the emergence of polycentric urban regions (Champion 2001; Hall/Pain 2006). Many scholars have attempted to conceptualise the urbanisation process in developed countries as a cyclical process (for an overview see Parr 2012). Most contributions look at the functional urban region, distinguishing between a core city and a subordinate ring of dependent urban development. In the literature, we can distinguish two important dimensions in analysing urban development (Parr 2012): the overall demographic development of the functional urban region (concentration/deconcentration) and the dynamics within the functional urban region (centralisation/decentralisation). Van den Berg et al. (1982) define four stages of urban development: urbanisation, suburbanisation, counterurbanisation and reurbanisation, each distinguished into two sub-phases where centralisation and decentralisation is either relative (i.e. corresponding trend but different intensity) or absolute (i.e. diverging trends) (see Table 1). Parr (2012) has refined this model by introducing different growth rates instead of absolute population growth.

For most of the second half of the twentieth century many cities in Western Europe and the US experienced centrifugal development patterns, first benefitting the suburbs and later resulting in counterurbanisation (Berry 1980; Champion 1989; Fuguitt 1985). Deindustrialisation and deconcentration resulted in population decline of most large cities, though the picture is far from being uniform (Turok/ Mykhnenko 2007). It is only towards the end of the century that we observed the resurgence of cities, not just economically but also demographically (Cheshire 2006; Turok/Mykhnenko 2007). This demographic recovery was picked up as a possibility as the last stage of development by Van den Berg et al. (1982). According to their model, reurbanisation was thought to occur in a context of a declining functional urban region, but nowadays the term is used to denote a wider range of transformative processes in cities, often without reference to the functional urban region (for an overview, see Rérat 2012). The model of Van den Berg et al. (1982) is important, not because of its predictive value or historical accuracy (for a critical appraisal, see Rérat 2012 and Parr 2012), but because they hinted at a new phase in the urbanisation cycle with a (relative) resurgence of the core city, at a time that was in the grip 
Tab. 1: Stages of urban development: Population change

\begin{tabular}{lllllll}
\hline $\begin{array}{l}\text { Stage of } \\
\text { Development }\end{array}$ & Classification Type & \multicolumn{4}{c}{ Population Characteristics } \\
\hline I Urbanisation & 1 & Absolute centralisation & ++ & - & + & \\
& 2 & Relative centralisation & ++ & + & +++ & Total \\
II Suburbanisation & 3 & Relative decentralisation & + & ++ & +++ & growth \\
& 4 & Absolute decentralisation & - & ++ & + & \\
III Counter- & 5 & Absolute centralisation & -- & + & - & \\
urbanisation & 6 & Relative centralisation & -- & - & --- & Total \\
IV Reurbanisation & 7 & Absolute centralisation & - & -- & --- & decline \\
& 8 & Relative centralisation & + & -- & - & \\
\hline
\end{tabular}

${ }^{1}$ Functional Urban Region

Note: The + and - signs indicate the strengths of population change.

Source: Adapted from Van den Berg et al. 1982: 36

of counterurbanisation and because their definition of reurbanisation emphasises the relationship between cities, suburbs and their wider hinterland.

This urges us to define our take on reurbanisation, in particular its substance and how it plays out geographically. Substantially, the question is whether reurbanisation is purely about demographic growth for a defined area (e.g. Rérat 2012) or whether it is about a qualitative change of the urban population and the built environment, particularly of the inner city (e.g. Buzar et al. 2007; Haase et al. 2010). Demographic growth is an essential criterion, but much of the literature on urban economy and gentrification suggests an ongoing "restratification of metropolitan society" and "changing physical appearance of the city" (Scott 2008: 62), which deserves our attention as one of the processes that sit within the reurbanisation family. Geographically, there is a related debate whether reurbanisation refers to the core city (usually the administrative city) or inner urban areas. The debate about reurbanisation would probably not have had the same resonance if it were not for an increase in urbanity through the physical and demographic renaissance of the inner cities. For our purpose, both geographies are legitimate as they focus on different processes at different levels of scale. We expect to find that centralisation tendencies, simply defined as higher growth rates (Parr 2012), within a city and the city region take place in parallel. Finally, the issue remains whether reurbanisation can be seen in isolation or whether it is related to wider developments in the city region. For Van den Berg et al. (1982), reurbanisation was clearly a process that would be detrimental to the urban ring. It is exactly this last issue that we feel receives insufficient attention in the academic debate.

The current evidence base on the effects of reurbanisation on the urban periphery is rather thin and inconclusive. In Switzerland, reurbanisation had no overall negative effects on suburban areas, but this was partly alleviated by a positive net migration and continued suburbanisation (Rérat 2012). A German study found 
that demographic shrinkage will particularly affect the housing markets in suburban areas, including single-family homes (Berndgen-Kaiser et al. 2014). There is an emerging body of literature focussing specifically on the suburbanisation of poverty. A study by Kavanagh et al. (2016) on Scottish cities discovered decentralisation trends, but only included data for the core city and thus neglected large parts of the urban area. Dutch studies confirm changing residential patterns within urban regions and an increasing tendency towards suburbanisation of low-income and migrant households, though described as an important undercurrent rather than a dominant trend (Hochstenbach/Musterd 2017; Van Gent/Musterd 2016). However, there is emerging evidence and experience to warrant further investigation of what happens to the urban periphery in an era where many core cities experience reurbanisation. Our concern is that small- and medium-sized towns in less prosperous urban regions might not benefit significantly from any overspill effects of reurbanisation and that established strategies attracting traditional suburban households, particularly young families, might not be sufficient to address this issue.

So far, this section has principally discussed observable trends and conceptualisations of change in city regions, but clearly spatial development does not occur in an institutional and policy vacuum. Urban planning policies and strategies and given "planning cultures" can influence processes such as reurbanisation. Recognising this, the following paragraphs consider the context within which change in the spatial in-between of the Manchester and Liverpool city regions takes place.

It is worth remarking first that urban containment has been a cornerstone of English planning since the 1940 s as a reaction to an interwar period marked by rapid housing development and concern at the rate of urbanisation and "ribbon development" (Williams-Ellis 1928). In the decades after the 1947 Town and Country Planning Act, a number of substantive planning goals were pursued, including urban containment, protection of the countryside and urban renewal. The state also sought to channel and structure planned dispersal of what was termed "overspill" urban population into "New Towns". The suburban and quasi-rural imaginary promoted by British planning doctrine (Taylor 1998) and housing developers in the twentieth century; the (perceived) obsolescence of many existing urban environments and their demolition; the planned rehousing of urban population beyond central city limits; and technological changes, such as the rise of private transport, also played their role in the hollowing out of core areas of cities (for an account of this process in Liverpool see Sykes et al. 2013). Decentralisation of population on such a massive scale, contributed to a vicious circle of urban economic and physical decline, which encouraged more of those who could to leave the city. Meanwhile, due to strict urban containment commuters were having to travel further from home to work (Hall 1974).

Increasingly in the 1970s and into the 1980s, wider structural changes led to economic turbulence, mass unemployment and urban unrest in a number of major cities. In response, state spatial policy took on an increasingly urban focus. Attention to inner-cities grew under Margaret Thatcher, who famously stated something needed to be done about "those inner cities" (Jacobs 1988), but it was only under New Labour after 1997 that the notion and in many respects reality of an "urban re- 
naissance" gained real traction. Under the Conservatives, government-led urban regeneration policy emphasised property and "physically"-led project planning with arguably a lack of strategic overview at the urban scale. These governments also favoured liberal deregulation which contributed to continued outward dispersal of development activity, away from urban cores sustaining the processes of decentralisation described earlier by Hall (1974). Some researchers evoked the notion of a counterurbanisation cascade to describe the trend of urban-rural migration (Champion 2005; Mitchel/ 2004), and it was only in the 1990s that the pace of urban decline slowed down and in some cases even showed signs of a reverse.

Alarmed by the sustained decline of cities, the New Labour government in 1997 set up an Urban Task Force (1999) whose final report Towards an Urban Renaissance paved the way for new investment in Britain's cities (Colomb 2007). This agenda was allied with investment in regenerating the big cities (especially the centres), "town centre first" policies for retail development and targets to increase the amount of new housing built on "brownfield" land to push regeneration and limit sprawl (Schulze Bäing/Wong 2012). This policy approach was seen generally as a success which has led to a "return of" and "return to" the city (Rae 2013). In a culture which has often been characterised as having anti-urban traits (Taylor 1998), there has been a slow shift of perceptions about cities, from them being viewed as a source and locus of problems to a recognition of their economic, social and cultural importance.

From the mid-2000s, city-regions were increasingly conceived as drivers of change in a more knowledge-based economy, though British cities were still underperforming in comparison with those in many other European countries - an issue often linked by researchers to institutional design and the need to find an appropriate scale at which to conceive and deliver development strategies (Parkinson 2016). This led to renewed attention on "functional" urban areas and the favouring of city-regions constituted of groupings of local authorities representing a coherent area larger than the "local" to generate critical mass. In the 2010s, "Combined Authorities" with a varying suite of powers and responsibilities for the local areas within their jurisdiction have been created with the first elections of Metro Mayors for these taking place 2017 (Sykes/Nurse 2017). This shift in emphasis and further institutionalisation of city regions generates new trade-offs between different areas within a city region, e.g. between the core city and secondary towns, peri-urban and rural areas. In Greater Manchester, the city-regional mayor campaign in 2017 become politicised around the issue of the emerging Greater Manchester Spatial Framework for the city region and its potential impacts on the city region's Greenbelt (Fitzgerald 2017).

In England, the transition through the stages of the model proposed by Van den Berg et al. (1982) has thus partly been driven by a policy framework and planning culture which has had both decentralising effects on urbanisation (New Towns and later the development of mostly private, mostly suburban, housebuilding) and certain centralising/reurbanising effects (strong urban containment, and urban regeneration policy). The reurbanisation tendencies which have gathered pace in the first decades of the $21^{\text {st }}$ century, and new processes of rebuilding institutional capacity 
to act at city regional scale thus, in many ways, mark a notable departure from the previous trends and experience outlined above, but they are not unproblematic raising issues such as:

- does this agenda privilege the largest cities and city regions at the expense of development beyond these?;

- how can shared agendas and solidarities be established between thriving urban cores and peripheries?;

- will the "devolution/decentralisation" of powers by the state be accompanied by adequate resourcing?;

- how will political processes work and consensus be built across new, or strengthened metropolitan territories?; will we witness rising political conflicts in the core-periphery relationship?; and,

- what happens to places on the peripheries, or those which lie on the edge of or even outside the ambit of such new territorial groupings?

It is to the consideration of one such area located between the city regions of Liverpool and Greater Manchester that the paper now turns.

\section{Data and methods}

The research combines a quantitative approach displaying regional spatial trends in the Mersey Belt with a qualitative approach analysing the policy options for a specific local authority in the spatial in-between of an urban region and how it addresses these spatial trends in a context of an urban renaissance.

The article looks at changes in the spatial distribution of population, jobs and deprivation to assess the implications of reurbanisation across the Manchester and Liverpool city regions in the North West of England since the beginning of the millennium. Measuring change is not easy as many indicators reflect only a specific moment in time, while being highly volatile and susceptible to external factors. Yet, starting with the early 2000s makes sense as for most cities in the UK the 2001 Census marked a turning point after decades of sustained population decline (Parkinson et al. 2006). Due to data availability, it is not possible to choose the same time period for each indicator, unless we want to rely on relatively dated Census records of 2011. The following indicators have been used:

- Small area population estimates 2002 and 2015 for Middle Layer Super Output Areas;

- Workplace population based on the National Statistics Socio-economic Classification (NS-SEC) 2001 and 2011 for Middle Layer Super Output Areas;

- Index of Multiple Deprivation 2004 and 2015.

There are limitations regarding data availability for spatial units and moments in time. The Census of population is only held every decade and the last one already dates from 2011. Therefore, we have used mid-year population estimates instead of census records. In addition, for Manchester a significant undercount in the 2001 
census has been reported (ONS 2004; Simpson 2007). Data has been collated for super output areas, which are comparable in population size. Middle layer super output areas (MSOA) have a population range of 5,000-15,000, which makes them sufficiently abstract as they are not distorted by small-scale change, while providing sufficient level of detail. The Index of Multiple Deprivation has been specifically designed to measure deprivation at small-area level and therefore uses lower level super output areas, which have a population range of 1,000-3,000 (Noble et al. 2006).

While stability of the census geography has been a priority, population dynamics required the modification of boundaries. Most output geographies have simply been split or merged, depending on the direction of population change. This poses a minor challenge to calculate changes when the geographical unit has changed and data reflecting the new boundaries has not been released. Fortunately, only a small percentage of areas are affected by boundary changes; values have been manually calculated, reflecting the combined input values in the case of a merger or using the combined output values in the case of a boundary split. Boundary splits tend to be concentrated in the inner-city areas, while mergers occurred more often in the urban fringe.

The policy case study of St Helens is based on findings from the PURE Hubs project which involved two student planning projects focussing on St Helens in 2013 and 2014, a two-day workshop with St Helens Council in 2013 and two follow-up interviews in 2014 and 2015 with the development plans manager and the countryside development officer of St Helens Council to explore in more detail the current situation and future development prospects of St Helens in its wider regional context. In addition, the St Helens case study is based on the analysis of policy documents, in particular a close reading of St Helen's Local Plan documents.

\section{$4 \quad$ Manchester, Liverpool and the spatial in-between}

Manchester and Liverpool are the two principal cities in the North West of England with a combined population in the conurbation of more than 5 million. Despite having two strong urban centres, the Mersey Belt is characterised by a polycentric urban structure with many sub-centres, notably the former new town of Warrington. Administratively the region is divided into three sub-regions since the abolition of regional structures in 2010. Greater Manchester and Liverpool City Region both have Combined Authority status, including a metro mayor granting them powers amongst others in the field of transport and strategic planning (Nurse et al. 2017). Warrington, although having strong functional linkages with both city regions, belongs to neither of those and forms a partnership with Cheshire. Nevertheless, it makes sense to look at them together as their urban areas are strongly interwoven (Green 2008) and the reframing of the Manchester and Liverpool city-regions as Atlantic Gateway is just the latest of a series of attempts to bring the two cities together (Dembski 2015). Both Manchester and Liverpool have been what is generally considered a shrinking city (Couch/Cocks 2013; Oswalt 2005). Initially, there were internal movements from the cities into the suburbs (suburbanisation), but from the 


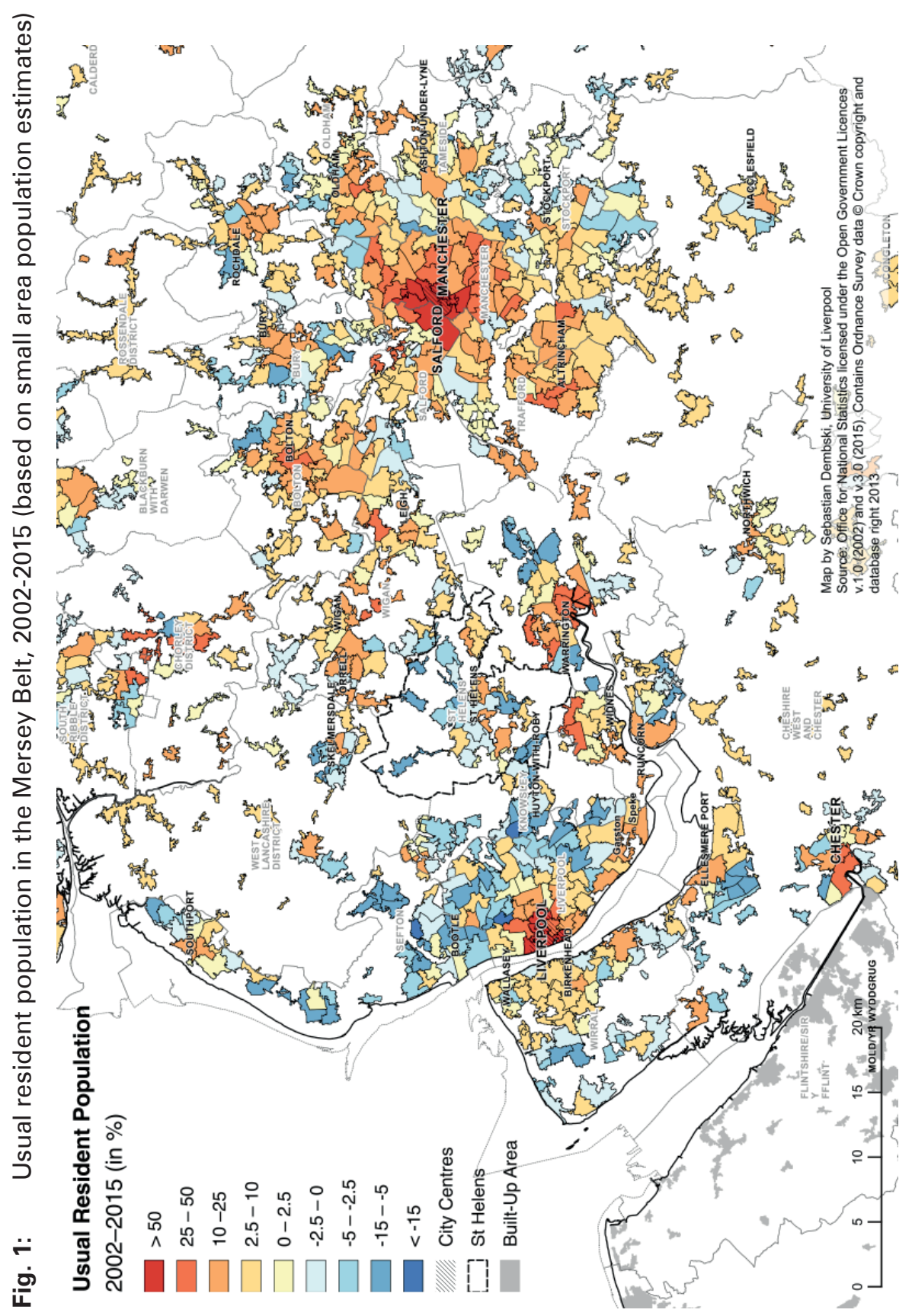


Tab. 2: Population change in different parts of the Mersey Belt, 2002-2015

\begin{tabular}{lrrr}
\hline & 2002 & 2015 & $\begin{array}{c}2002-2015 \\
\text { in \% }\end{array}$ \\
\hline Greater Manchester & & & +9.2 \\
$\quad$ Manchester & $2,485,283$ & $2,748,280$ & +23.8 \\
$\quad$ Ring & 428,221 & 530,292 & +6.2 \\
Liverpool City Region & $2,094,993$ & $2,225,870$ & +2.6 \\
$\quad$ Liverpool & $1,485,289$ & $1,524,558$ & +7.8 \\
$\quad$ Ring & 443,117 & 478,580 & +0.4 \\
Cheshire and Warrington & $1,041,505$ & $1,045,978$ & +5.7 \\
Mersey Belt & 867,620 & 917,004 & +6.6 \\
\hline Northwest Region & $4,876,123$ & $5,197,724$ & +5.7 \\
United Kingdom & $6,784,880$ & $7,173,835$ & +9.7 \\
\hline
\end{tabular}

Source: own calculations based on the ONS mid-year population estimates for local authorities

late 1970 s onwards, the city regions as a whole declined (counterurbanisation) (Dorling/Atkins 1995), mirroring the stages of urban development. So, what happened in the Northwest in the age of the urban renaissance?

The Mersey Belt provides clear evidence of reurbanisation, with the strongest population growth in the core cities and relatively stronger growth in the urban centres (Fig. 1). Both core cities have been clearly the drivers of population growth in their respective city regions, with Manchester being one of the fastest growing cities in the UK (Rae 2013). The position of Manchester as the economic powerhouse of the North is also mirrored in the much higher population growth of Greater Manchester compared to Liverpool City Region, where growth is on balance almost entirely confined to the core (Tab. 2). The urban renaissance is most visible in the central areas of Liverpool and Manchester, the latter extending into parts of Salford and Trafford, which witnessed population growth close to or above 100 percent. Both city centres have been targeted by a range of regeneration schemes from the 1980s onwards (Harding et al. 2010; Sykes et al. 2013), finally resulting in new residential developments in the almost deserted inner urban areas. This trend towards reurbanisation, although on a much smaller scale, can also be observed in the town centres, which tend to have higher population growth than the rest of the town. What we observe is a dual process of reurbanisation, with concentration at the scale of the city region and local authorities.

Despite the growth of smaller town centres, there is evidence that the periphery has comparatively lost out. This is evident in the very moderate population growth in the urban periphery of Liverpool (+0.4 percent), but also in the much lower population growth of the Manchester periphery (6.2 percent) compared with the core. Taken into account that during the same period 2002-2015 the UK's population had grown by almost 10 percent ( 5.7 percent in the Northwest Region), driven by a com- 


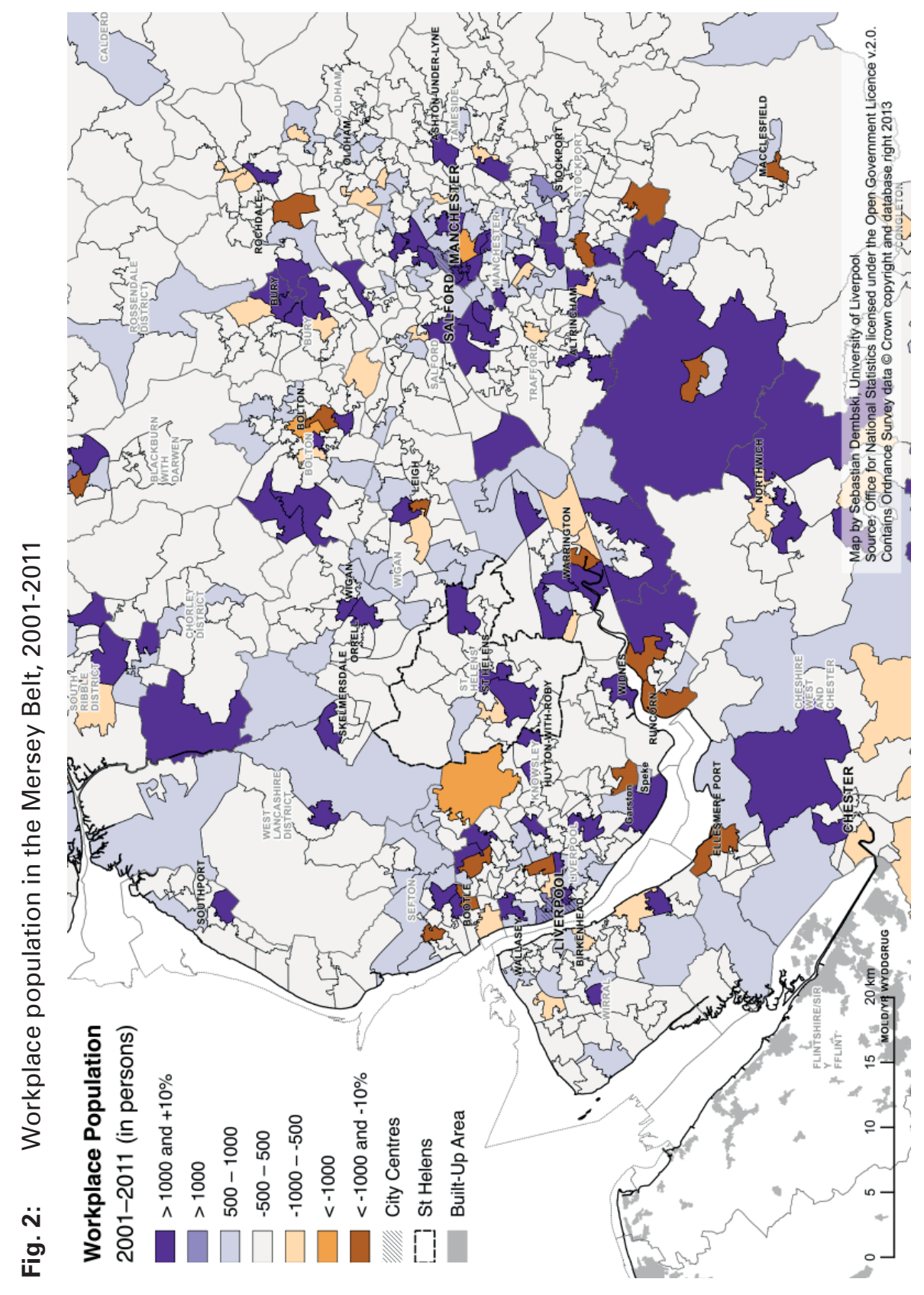


paratively high fertility rate and immigration, we can see a blue- and yellow-coloured ring of "underperforming" areas around both core cities. Only a few areas outside town centres show high growth rates, usually indicating large-scale house building schemes, which in the case of Warrington forms part of the legacy of the UK's new towns policy. The reasons for their decline are varied. In particular in many suburban areas, this is simply the result of an ageing population and changing household structure, rather than the visible deterioration of a neighbourhood. Many cities still struggle with the effects of deindustrialisation, particularly in the northern part of Greater Manchester (Harding et al. 2010). In a few cases, rapid population decline is the result of clearances through urban renewal programmes (Couch/Cocks 2013; Leather/Nevin 2013; Sykes et al. 2013). The suburban ring is far from being homogeneous and each colour on the map has its own story to tell.

Regarding the number of jobs, urban cores have fared well again, but job growth is more dispersed (Fig. 2). First of all, the number of jobs has generally increased between the 2001 and 2011 censuses, mainly driven by population growth due to immigration (Dustmann/Frattini 2014). Some caution is required as the 2011 Census was still overshadowed by the aftermath of the 2008 financial and economic crisis and the economy only started to pick up again (McCann 2016). The central urban areas had already by far the highest concentration of jobs and substantially expanded their employment base. Areas with high job losses tend to be dominated by industrial activities, including the Port of Liverpool, and are usually located in the urban fringe. However, other areas in the urban fringe are economically very dynamic, not least the two airports, both at the southern edge of the administrative boundaries of Manchester and Liverpool respectively, and some of the strategic regional sites located in out-of-town locations such as the Omega and Birchwood business parks in Warrington (Wray 2011). Yet it is not just absolute numbers, but also the types of jobs. The three-class National Statistics Socio-Economic Classification (Fig. 3) provides a simplified labour market hierarchy of "higher managerial, administrative and professional occupations", "intermediate occupations" and "routine and manual occupations" (ONS 2010). Focussing on the lower end of the labour market, we unsurprisingly find that the city centres have a relatively low share of employees in routine and manual occupations. These tend to concentrate in less central areas, particularly in the less affluent northern part of the Mersey Belt.

The Mersey Belt is home to some of England's most deprived communities, with severe pockets of deprivation in the two core cities but also in smaller towns such as Birkenhead, Kirkby and Rochdale (Fig. 4). The Index of Multiple Deprivation (IMD) is a composite index measuring deprivation for small areas and ranks all neighbourhoods (LSOA) in England from most to least deprived. ${ }^{1}$ It is important to stress that it is a measure of deprivation and is unsuitable to indicate prosperity. Deprivation in

1 The Index of Multiple Deprivation measures deprivation across seven domains (weightings in brackets): Income Deprivation (22.5 percent), Employment Deprivation (22.5 percent), Education, Skills and Training Deprivation (13.5 percent), Health Deprivation and Disability (13.5 percent), Crime (9.3 percent), Barriers to Housing and Services (9.3 percent), and Living Environment Deprivation (9.3 percent). A detailed technical report is available (DCLG 2015). 


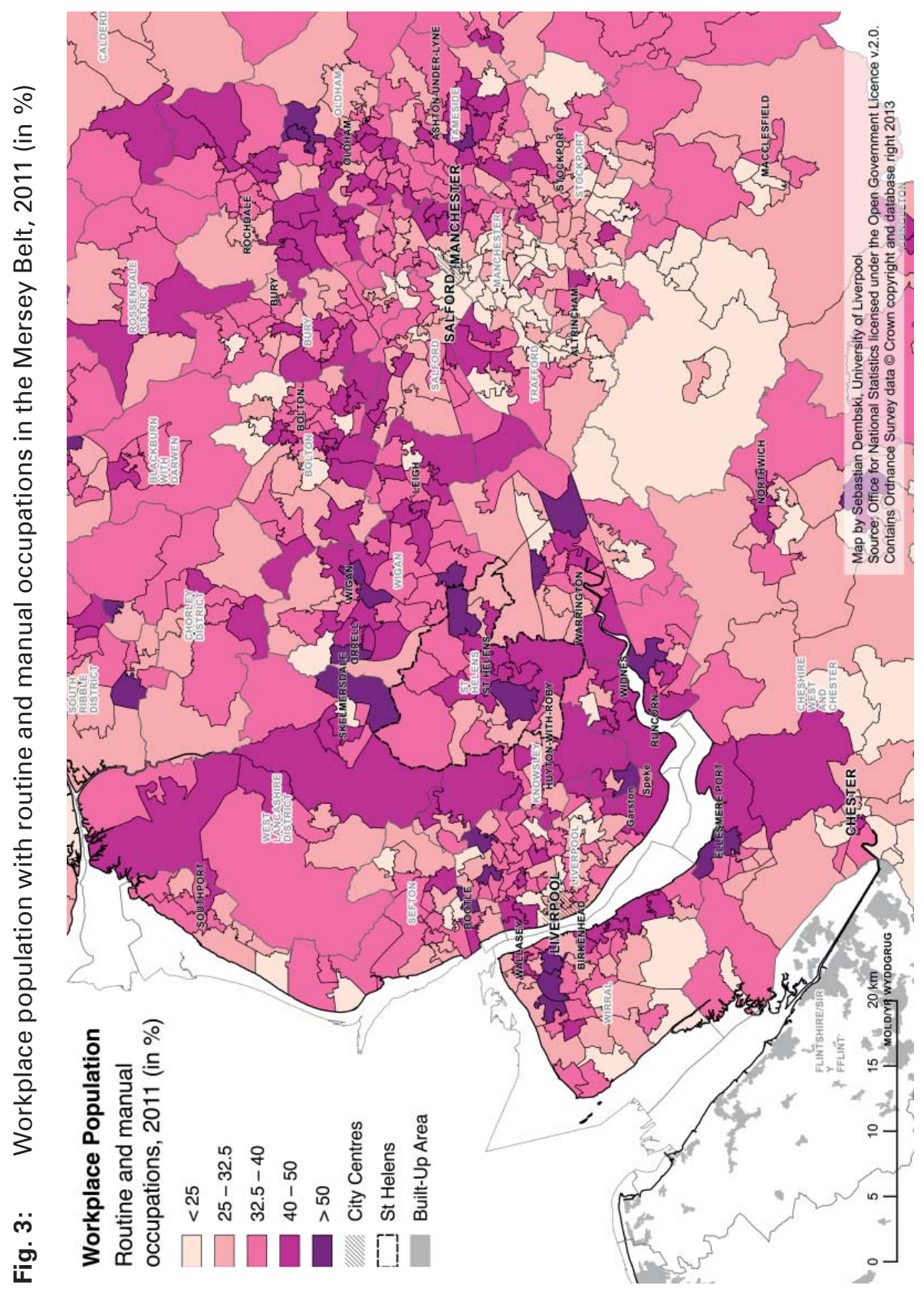




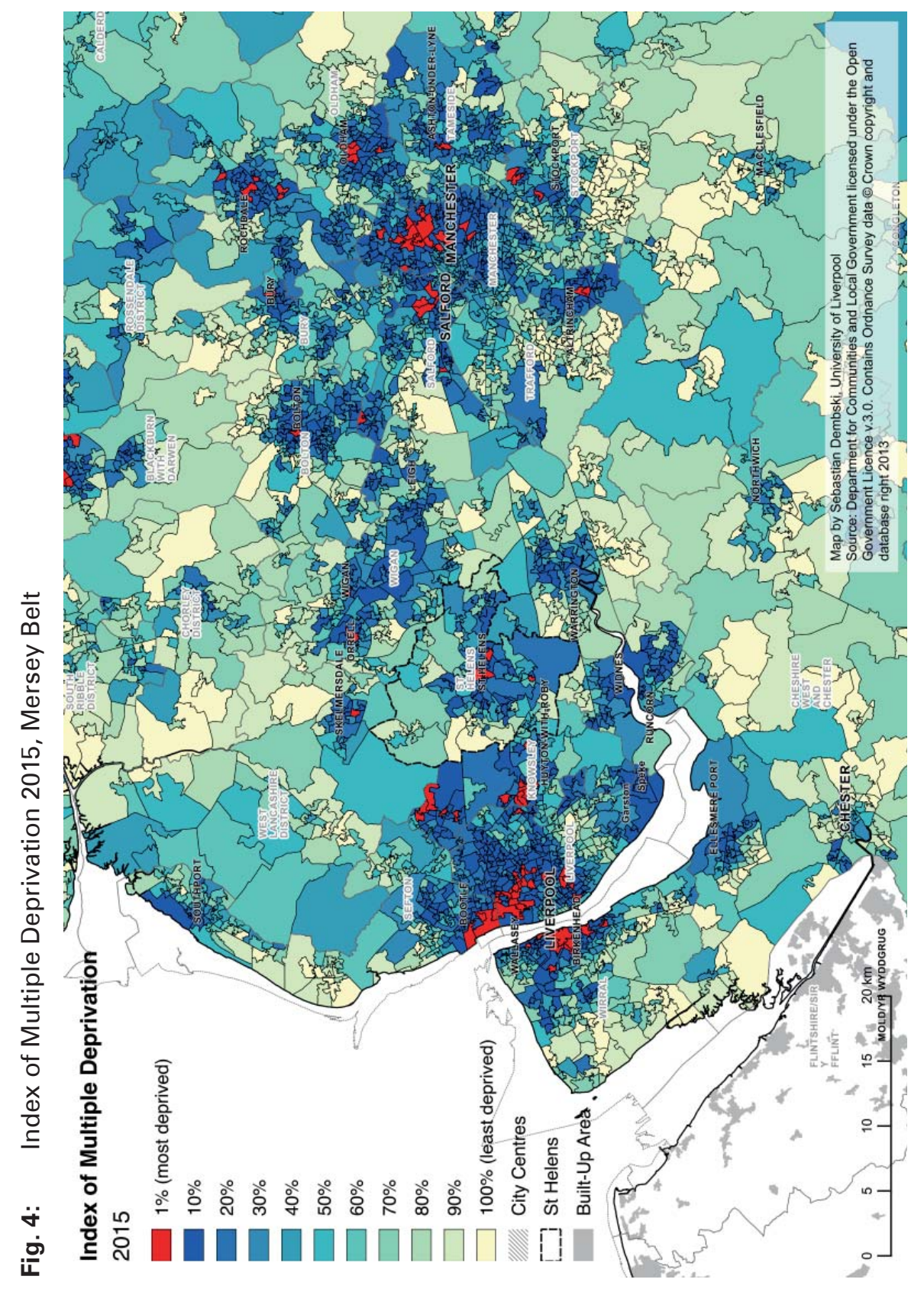


this part of England tends to be concentrated in urban - as opposed to rural - areas. Large parts of the cities and towns in the Mersey Belt are amongst the 20 percent of the most deprived areas in England. While structural deprivation is traditionally concentrated in the core cities, some of the most deprived neighbourhoods of England are also located in smaller towns in the urban fringe (e.g. Rochdale). While the Index of Multiple Deprivation is not designed to compare absolute levels of deprivation, it allows us to compare the relative position of areas between different editions (DCLG 2015).

Comparing deprivation between 2004 and 2015 underlines the narrative of reurbanisation. The Liverpool and Manchester city regions have more areas that comparatively improved their position. While the city centres have never been the most deprived areas anyway, they have clearly improved their relative position through the advent of city-centre living and more up-market residential units (A/len 2007). Again, the effect of Manchester's city centre regeneration radiates further than Liverpool's, reflecting the head start of urban regeneration in Manchester (Harding et al. 2004). Nevertheless, both cities continue to have large areas with persistent deprivation, particularly to the north, which have seen only marginal improvements, if at all, despite being targeted repeatedly through various area-based regeneration initiatives (Batey/Brown 2007). Again, we can notice a considerably higher number of areas that have stagnated or lost ground in the fringes of the city regions, particularly east of Greater Manchester (e.g. Rochdale, Oldham and Stockport), but also places like Ellesmere Port and St. Helens near Liverpool. The real "losers" of the urban renaissance in the North West, however, can be found in places like Blackpool, Blackburn and Burnley, which are just off the map. While the Index of Multiple Deprivation provides no conclusive evidence - there is also the theoretical possibility that all neighbourhoods have improved, albeit at different degrees - suburban towns seem to face increasing challenges. Having said this, despite all the reports on its buoyant economy, Manchester is currently the local authority with the highest levels of deprivation.

Our brief analysis of key indicators confirms the wider trend of a renaissance of the inner cities, but also points at emerging evidence that it might come at a cost of concentrating a new "problem zone" in working-class suburbs in the innerurban fringe of city-regions. It is here that we find the unfavourable mix of population decline, loss of industrial employment and increasing deprivation. With few exceptions, the small and medium towns in the spatial in-between, i.e. neither city nor countryside, seem to suffer. This is not only a problem for the local authorities and neighbourhoods in question, but increasingly proves to be a national problem, as the recent vote to leave the European Union has demonstrated: the vote for remain was generally stronger in the core cities and the prosperous hinterlands of London than in the suburbs and peripheral regions (Los et al. 2017). We will now look closer into one of them: the metropolitan borough of St Helens, 15 kilometres east of Liverpool. 


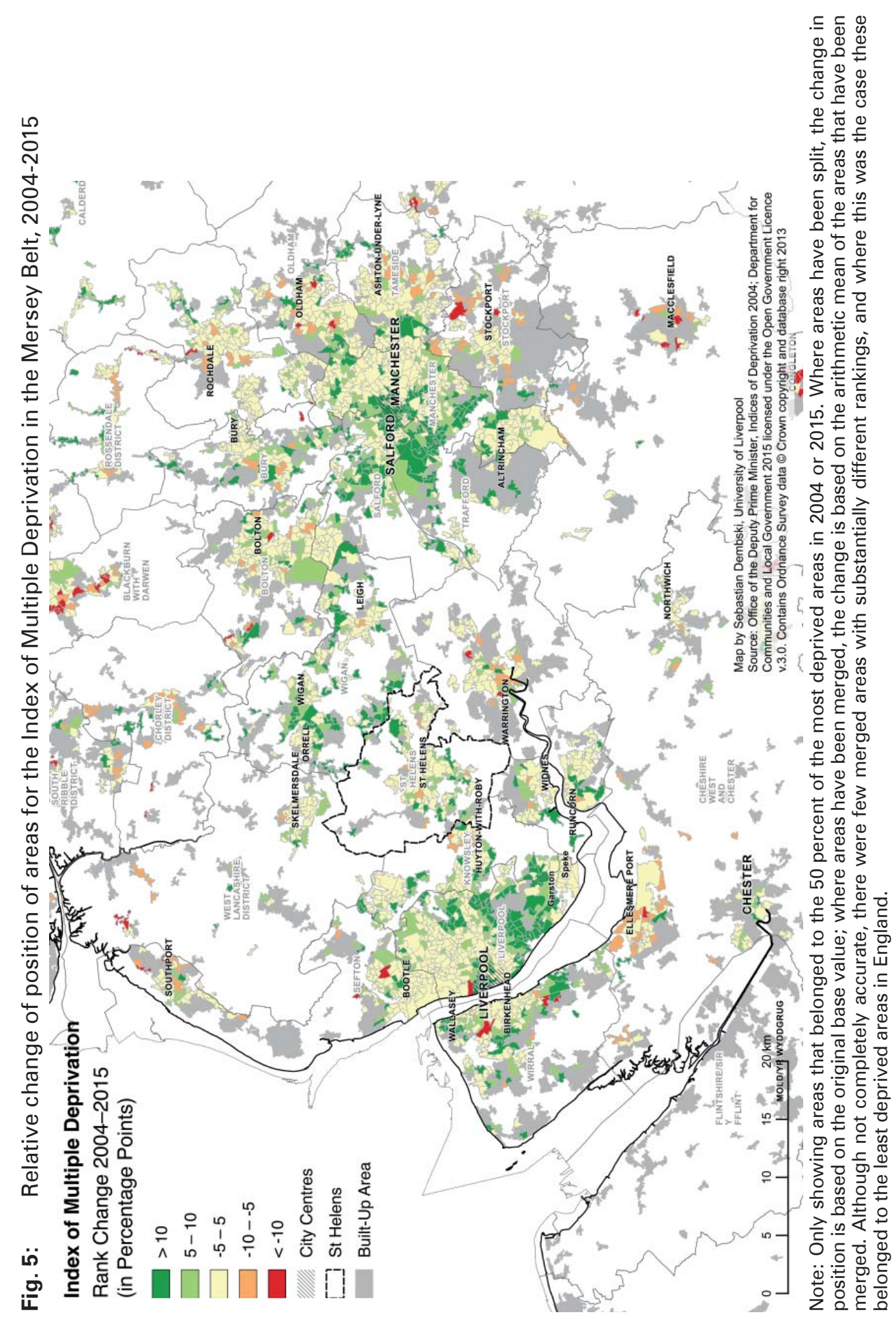




\section{$5 \quad$ St Helens: Finding its place in the periphery}

St Helens, a local authority district located in the northern part of the Mersey Belt with a population of about 175,000 , represents a typical case of a town on the urban periphery of a large conurbation. The district is named after its largest town, St. Helens, but includes a number of smaller independent settlements. The borough's area covers about $135 \mathrm{~km}^{2}$, of which more than half is open space, protected by greenbelt designation. St Helens' population grew rapidly following the industrial revolution in the nineteenth and twentieth centuries ( $A$ Vision of Britain through Time 2017) owing to its location in the South Lancashire Coalfield, which enabled other heavy industries to thrive, most notably glass manufacturing. The decline of major industries, in particular manufacturing and coal mining, has created longlasting structural problems for the borough, facing high unemployment and population decline in the 1980s and 1990s. While the borough has successfully overcome the trend of population decline - since 2007 the population has been growing at a modest rate - it is still struggling with the aftermath of deindustrialisation. It is now facing the typical challenge of an industrial town in a major metropolitan area: how to regenerate and grow the borough with neither the major assets of a thriving city centre economy nor the attraction of the English countryside. The example of St Helens illustrates how the problems are perceived and discusses the responses of the borough to these trends.

The key challenge for St Helens is to grow the economy and the population. While population decline was brought to a halt by 2007 (St Helens Council 2016), growth has been only very modest and primarily driven by a few large suburbanstyle housing developments following on from the designation of the area as MidMersey Growth Point in 2008, a government-funded regeneration initiative. From a city-regional perspective, one could see this as reurbanisation, although considering the form and density of the new housing, it could also be described as an example of suburbanisation within the conurbation. In England's major cities including Liverpool and Manchester, reurbanisation mainly took the form of high-density, compact developments in the form of blocks of flats in and around the city centres, complemented by in-fill developments on previously developed land (Schulze Bäing/Wong 2012). Towns like St Helens also saw some development of flats in the centre in the early 2000s. But unlike in nearby Liverpool or Manchester, these blocks of flats are fairly low-priced, and being occupied by many short-term renters facing a big churn of population. In terms of demographic developments, ageing population and young people leaving have been identified as a key challenge. Hence, a particular concern for the borough is the cost of housing an elderly population. The loss of many manufacturing jobs also contributed to a growth of areas characterised by multiple deprivation, particularly in the neighbourhoods adjacent to the former industries. St Helens is the $36^{\text {th }}$ most deprived local authority district in England (total 326) and its relative position has deteriorated compared to previous editions of the Index (St Helens Council 2016). Some areas are among the worst 1 percent in the country and 24 percent of the population live within the 10 percent of the most deprived LSOAs according to the IMD 2015 (Fig. 4). Unlike some of the deprived areas 
in larger cities with a high share of transient populations, the more deprived areas in St Helens are fairly stable, and it is therefore going to take a long time to change the patterns of deprivation. There is a legacy of derelict land which is unsuitable for the location preferences of new businesses and costly to redevelop for housing. The unemployment rate is above the regional and national average (St Helens Council 2016) and St Helens is the local authority with the highest share of routine and manual occupations in the North West (2011 Census). A key challenge is to connect employment sites with deprived areas, where car ownership rates are low.

These problems are long recognised and St Helens was targeted by several regeneration initiatives from the EU under the Merseyside Objective 1 programmes and under New Labour's drive for an urban renaissance in the 1990s and 2000s, but most of these initiatives focussed on the deprived inner neighbourhoods of England's major cities as part of the so-called Sustainable Communities Agenda (ODPM 2003). This has led to a temporary improvement in deprivation levels, both for the whole borough and in some of the most deprived neighbourhoods between 2004 and 2007 (St Helens Council 2008). However, St Helens was not included in the multi-million pound schemes of the Housing Market Renewal (HMR) initiative addressing failed housing markets, as it did not face the same level of challenges of poor quality housing stock and dereliction to be found in some other cities and towns of Northern England.

A particular problem for St Helens results from the increasing emphasis on city regions and its central, yet peripheral geographical location. This seemingly paradoxical situation stems from the fact that St Helens is located at the interface of Manchester and Liverpool. St Helens is part of the Liverpool City Region Combined Authority, while its eastern neighbour Wigan is part of the Greater Manchester Combined Authority. Before 2010, the regional spatial strategy for the North West of England provided a structure for local development, including housing designations. Since the abolition of regional institutions following a change in government in 2010, intra-regional cooperation on planning matters has been a challenge. The revocation of the Regional Strategy means that there is no regional guidance, for instance regarding housing development. This was meant to be provided as part of the Localism Act 2011, which introduced the legal duty to cooperate in planning matters between planning authorities, but this only implies engagement in a constructive dialogue, not necessarily reaching agreement. St Helens leads the housing theme within Liverpool City Region, but the relationship with the Greater Manchester area, including neighbouring Wigan, has hardened since the start of the new city-regional combined authority for Greater Manchester. Apart from bi-annual meetings as part of the legal duty to cooperate, there is little contact. Warrington is not part of these new regional bodies.

Many of the local policy responses are quite conventional, aiming to drive growth. The borough is currently developing a new Local Plan, which proposes the release of greenbelt land for new residential and employment development. Most neighbouring districts have undertaken their own greenbelt reviews, or are in the process of doing so, with a similar outcome. Warrington, one of the third-generation new towns to the south, is one of the key competitors for inhabitants and invest- 
ments with large sites under development. New residential development is seen as the primary driver of population growth in St Helens, with a planned net completion rate of 570 dwellings per annum. The current Core Strategy, the key strategic local planning document, aims to focus on locations in the core settlement area of St Helens, with particular focus on the more deprived neighbourhoods (St Helens Council 2012). In terms of future housing growth executive housing is seen as an option to attract more affluent residents. These types of development are likely to be in the outer parts of the borough, increasing pressure on greenbelt land. On the one hand, St Helens offers an affordable alternative for those looking for suburban housing locations in the middle of the Mersey belt. On the other hand, many of those new residents may have jobs elsewhere and may prefer to use retail destinations in neighbouring towns or in suburban shopping centres. Most of the new employment sites are located near the major motorways, focussing on so-called "big shed" developments such as warehouses for logistics. While there seems to be demand for these sites, the employment effects of such developments tend to be modest and at the lower end of the labour market. Many of the brownfield sites that were relatively easy to develop have already been reused or converted, while others are regarded as unsuitable for the type of large-scale uses that are currently in demand (St Helens Council 2016). The ambition remains, however, to continue the pre-2010 national policy to deliver locally 60 percent of housing on previously developed land.

One initiative which demonstrates the effort of places in the urban periphery like St Helens to define a new role within wider regional territories is the EU Interreg IVb Project PURE Hubs. This project aimed to capitalise on what is distinctive about the borough's geographic context, in particular the fact that unlike the core urban areas of Manchester and Liverpool, large parts of urban St Helens are in close proximity to open countryside. The project aimed at enhancing the social and economic relationships between urban communities and adjacent rural areas. Within the PURE Hubs project St Helens Council worked with the University of Liverpool to transform a rural-urban fringe area of open spaces, agricultural land, woodland and former industrial sites in the south of the town, into a community-supported leisure destination. This was branded as Bold Forest Park, within the wider regional Mersey Forest initiative. The aim was for the area to be attractive to locals, but also tourists given its accessibility by rail and road from Liverpool and Manchester. An Area Action Plan for the area referred to options including developing mountain bike tracks and horse riding trails (St Helens Council 2015). Large parts of the area have been converted from former industrial use into open countryside as an investment in St Helens' natural capital, but the hope was also that developing a leisure destination would have additional positive social, economic and health effects for the relatively deprived southern neighbourhoods of St Helens.

Initiatives such as the "path to employment" scheme by the environmental charity Groundwork try to encourage households with a history of multiple generation unemployment in deprived areas to get out every day and work on a regular basis, by helping to develop and maintain the park. This also responds to health, another key concern in St Helens, partly due to its past of heavy industries. Another interest- 
ing scheme in St Helens mentioned by the local planners is that a member of the borough's planning team is a travel trainer who goes to areas working with unemployed people, showing them how to use public transport, cycling and walking to link to jobs, particularly in the growing Omega development south of the Borough in Warrington. In this context, there are also plans for new cycle links through the area of Bold Forest Park to this area of employment in Warrington located south of St Helens.

The case study of St Helens is emblematic for the challenges faced by numerous towns during the urban renaissance and an increasingly city-centric policy focus. It is a balancing act between the needs of communities experiencing long-term deprivation and raising the socio-economic profile. Like many other towns, St Helens has severe pockets of deprivation, which could potentially benefit from the new employment opportunities in logistics and similar sectors arising in the borough. At the same time, these developments reinforce an economic structure centred on routine and manual employment. Attracting more affluent households to the borough is clearly the intention of local planners, even if this might turn parts of the borough into dormitory settlements and not benefit the wider local economy as jobs and retail destinations for these new residents might be outside of the borough. The Bold Forest Park initiative in the south of the Borough is one attempt to broaden the appeal of St Helens, both for its existing and potential new residents, while potentially also providing the base for a new visitor economy.

\section{What futures for the urban periphery?}

This article started with an appreciation of the urban renaissance of second-tier cities, in particular those in economically less prosperous regions that followed in the shadow of world cities such as London, and reflected how the urban renaissance unfolds on the scale of the wider urban region. We have carried out a simple geospatial analysis using demographic, social and economic indicators to map changes in the Mersey Belt since the beginning of the millennium, which was marked by strong urban policies focussing on the regeneration of English cities, and explored the consequences for St Helens, a typical town in the fringe of an urban region.

There is strong evidence of reurbanisation in the Mersey Belt, but not if we apply the exact definition of spatial-cycle models such as by Van den Berg et al. (1982). Both core cities experience higher growth rates than surrounding local authorities and within cities the highest growth rates are usually found in the centre. Notwithstanding all definitional issues of core and ring based on relatively arbitrary municipal boundaries, reurbanisation manifests itself as a relative concentration of population in a context of growing functional urban regions in the Mersey Belt, which would concur with the idea of urbanisation. Population data suggests that the reurbanisation phase was either very short or has been passed over. Reurbanisation in this sense might simply denote that a new stage in the spatial cycle has begun, highlighting the social, cultural and economic importance of cities fuelling demographic growth. 
Yet, the analysis of the Manchester and Liverpool city-regions warns us that despite a general context of sustained population growth in the UK and a general climate of an urban renaissance, urban shrinkage and further socio-economic decline pose a serious risk for a large number of places in the urban periphery. This is not to say that deprivation is to disappear from cities, nor that all places in the urban periphery are affected in the same way. Both core cities still rank amongst the most deprived local authorities in the country. Similarly, the exclusiveness of certain rural communities in the vicinities of cities is protected by green belt, keeping urban development at bay and house prices high (Sturzaker/Me/l 2016). Many dormitory and industrial towns, however, are struggling as they lack the character and attractiveness of affluent villages and the vibrancy of big cities. Are these becoming the potential overspill locations for the "victims" of the gentrification of inner cities (Hochstenbach/Musterd 2017)? What we have observed so far, is a process of levelling out the difference between core and ring, but with very marked socio-spatial differentiation within both the cities and the urban fringe.

This article highlights the potential issues arising in the urban fringe as a downside of reurbanisation It corroborates findings in other studies suggesting changes in the demographic composition of cities and their hinterland (e.g. Hochstenbach/ Musterd 2017; Van Gent/Musterd 2016). It requires further and more detailed research on the effects of reurbanisation, for instance using census flow data to investigate the migration patterns of population according to their socio-economic and demographic properties. It also urges us to critically examine the policy options for places in the periphery like St Helens and to investigate the institutional conditions under which policies are being pursued. The current trend of suburban housing estates and warehouse developments offering mainly routine jobs may exacerbate the already existing divide between cities and their hinterland, or between urban and non-urban lifestyles, potentially giving rise to new political conflicts.

\section{Acknowledgements}

Earlier versions of this paper have been presented at the workshop Urban Policies, Spatial Re-balancing and City-Regions, 20 May 2015 in Manchester, UK and the Polycentric City Regions in Transformation conference, 11-13 June 2015 in Essen, Germany. The case study of St Helens was part of the Interreg IVB project PURE Hubs, running from 2012 to 2015 in which the University of Liverpool and St Helens Council were project partners. We would like to acknowledge Chris Couch's comments on an earlier version of this paper. The usual disclaimer applies. We would also like to thank the editors of this special issue to present this work. 


\section{References}

A Vision of Britain through Time 2017: [URL: http://www.visionofbritain.org.uk/ unit/10102753/cube/TOT_POP, 11.4.2017].

Albecker, Marie-Fleur; Fol, Sylvie 2014: The Restructuring of Declining Surburbs in the Paris Region. In: Pallagst, Karina; Martinez-Fernandez, Cristina; Wiechmann, Thorsten (Eds.): Shrinking Cities: International Perspectives and Policy Implications. New York: Routledge: 78-98.

Allen, Chris 2007: Of urban entrepreneurs or 24-hour party people? City-centre living in Manchester, England. In: Environment and Planning A 39,3: 666-683 [doi: 10.1068/ a37302].

Audirac, Ivonne et al. 2012: Declining suburbs in Europe and Latin America. In: International Journal of Urban and Regional Research 36,2: 226-244 [doi: 10.1111/j.14682427.2011.01093.x].

Batey, Peter; Brown, Peter 2007: The spatial targeting of urban policy initiatives: a geodemographic assessment tool. In: Environment and Planning A 39,11: 2774-2793 [doi: 10.1068/a38519].

Berndgen-Kaiser, Andrea et al. 2014: Demography-driven suburban decline? At the crossroads: mature single-family housing estates in Germany. In: Journal of Urbanism: International Research on Placemaking and Urban Sustainability 7,3: 286-306 [doi: 10.1080/17549175.2013.879456].

Berry, Brian J. L. 1980: Urbanization and Counterurbanization in the United States. In: The Annals of the American Academy of Political and Social Science 451,1: 13-20 [doi: 10.1177/000271628045100103].

Blanco, Hilda et al. 2009: Shaken, shrinking, hot, impoverished and informal: emerging research agendas in planning. In: Progress in Planning 72,4: 195-250 [doi: 10.1016/j. progress.2009.09.001].

Brake, Klaus; Herfert, Günter (Eds.) 2012: Reurbanisierung: Materialität und Diskurs in Deutschland. Wiesbaden: Springer VS.

Buzar, Stefan; Hall, Ray; Ogden, Philip E. 2007: Beyond Gentrification: The Demographic Reurbanisation of Bologna. In: Environment and Planning A 39,1: 64-85 [doi: 10.1068/ a39109].

Champion, Anthony G. 1989: Counterurbanization in Britain. In: The Geographical Journal 155,1: 52-59 [doi: 10.2307/635380].

Champion, Anthony G. 2001: A Changing Demographic Regime and Evolving Poly centric Urban Regions: Consequences for the Size, Composition and Distribution of City Populations. In: Urban Studies 38,4: 657-677 [doi: 10.1080/00420980120035277].

Champion, Tony 2005: The counterurbanisation cascade in England and Wales since 1991: the evidence of a new migration dataset. In: Belgeo 1-2: 85-102 [doi: 10.4000/ belgeo.12440].

Cheshire, Paul C. 2006: Resurgent Cities, Urban Myths and Policy Hubris: What We Need to Know. In: Urban Studies 43,8: 1231-1246 [doi: 10.1080/00420980600775600].

Colomb, Claire 2007: Unpacking New Labour's 'urban renaissance' agenda: towards a socially sustainable reurbanization of British cities? In: Planning, Practice and Research 22,1: 1-24 [doi: 10.1080/02697450701455249].

Couch, Chris et al. 2005: Decline and sprawl: an evolving type of urban development observed in Liverpool and Leipzig. In: European Planning Studies 13,1: 117-136 [doi: 10.1080/0965431042000312433]. 
Couch, Chris; Cocks, Matthew 2013: Housing Vacancy and the Shrinking City: Trends and Policies in the UK and the City of Liverpool. In: Housing Studies 28,3: 499-519 [doi: 10.1080/02673037.2013.760029].

DCLG (Department for Communities and Local Government) 2015: The English Indices of Deprivation 2015: Technical report. London: DCLG.

Dorling, Daniel; Atkins, David 1995: Population density, change and concentration in Great Britain 1971, 1981 and 1991. Studies on Medical and Population Subjects No. 58. London: HMSO.

Dustmann, Christian; Frattini, Tommaso 2014: The Fiscal Effects of Immigration to the UK. In: The Economic Journal 124,580: F593-F643 [doi: 10.1111/ecoj.12181].

Fitzgerald, Todd 2017: Greater Manchester's mayoral candidates row over region's housing masterplan. In: Manchester Evening News, 12.1.2017 [http://www.manchestereveningnews.co.uk/news/greater-manchester-news/greater-manchesters-mayoral-candidates-row-12445676, 12.4.2017].

Fuguitt, Glenn V. 1985: The Nonmetropolitan Population Turnaround. In: Annual Review of Sociology 11: 259-280 [doi: 10.1146/annurev.so.11.080185.001355].

Gallent, Nick; Bianconi, Marco; Andersson, Johan 2006: Planning on the Edge: England's Rural-Urban Fringe and the Spatial-Planning Agenda. In: Environment and Planning B: Planning and Design 33,3: 457-476 [doi: 10.1068/b31171].

Green, Nick 2008: City-states and the spatial in-between. In: Town and Country Planning 77,5: 224-231.

Haase, Annegret et al. 2010: Emergent spaces of reurbanisation: exploring the demographic dimension of inner-city residential change in a European setting. In: Population, Space and Place 16,5: 443-463 [doi: 10.1002/psp.603].

Hall, Peter 1974: The Containment of Urban England. In: The Geographical Journal 140,3: 386-408.

Hall, Peter; Pain, Kathy 2006: The Polycentric Metropolis: Learning from Mega-City Regions in Europe. London: Earthscan.

Harding, Alan et al. 2004: Re-inventing cities in a restructuring region? The rhetoric and reality of renaissance in Liverpool and Manchester. In: Boddy, Martin; Parkinson, Michae/ (Eds.): City Matters: Competitiveness, Cohesion and Urban Governance. Bristol: Policy Press: 33-50.

Harding, Alan; Harloe, Michael; Rees, James 2010: Manchester's Bust Regime? In: International Journal of Urban and Regional Research 34,4: 981-991 [doi: 10.1111/j.14682427.2010.01013.x].

Hochstenbach, Cody; Musterd, Sako 2017: Gentrification and the suburbanization of poverty: changing urban geographies through boom and bust periods. In: Urban Geography [doi: 10.1080/02723638.2016.1276718].

Hoggart, Keith (Ed.) 2005: The City's Hinterland: Dynamism and Divergence in Europe's Peri-Urban Territories. Aldershot: Ashgate.

Jacobs, Michae/ 1988: Margaret Thatcher and the inner cities. In: Economic and Political Weekly 23,38: 1942-1944.

Kavanagh, Leo; Lee, Duncan; Pryce, Gwilym 2016: Is Poverty Decentralizing? Quantifying Uncertainty in the Decentralization of Urban Poverty. In: Annals of the American Association of Geographers 106,6: 1286-1298 [doi: 10.1080/24694452.2016.1213156]. 
Leather, Philip; Nevin, Brendan 2013: The Housing Market Renewal programme: origins, outcomes and the effectiveness of public policy interventions in a volatile market. In: Urban Studies 50,5: 856-875 [doi: 10.1177/0042098012449667].

Los, Bart et al. 2017: The mismatch between local voting and the local economic consequences of Brexit. In: Regional Studies 51,5: 786-799 [doi: 10.1080/00343404.2017.1287350].

McCann, Philip 2016: The UK Regional-National Economic Problem: Geography, Globalisation and Governance. Abingdon: Routledge.

Mitchell, Clare J. A. 2004: Making sense of counterurbanization. In: Journal of Rural Studies 20,1: 15-34 [doi: 10.1016/S0743-0167(03)00031-7].

Noble, Michael et al. 2006: Measuring Multiple Deprivation at the Small-Area Level. In: Environment and Planning A 38,1: 169-185 [doi: 10.1068/a37168].

Nurse, Alexander; Chen, Chia-Lin; Desjardins, Xavier 2017: The Northern Powerhouse: a comparative perspective. In: Town Planning Review 88,4: 383-400 [doi:10.3828/ tpr.2017.25].

ODPM (Office of the Deputy Prime Minister) 2003: Sustainable communities: building for the future. London: ODPM.

ONS (Office for National Statistics) 2004: 2001 Census: Local Authority Population Studies: Full report. ONS.

ONS (Office for National Statistics) 2010: Standard Occupational Classification 2010. Volume 3: The National Statistics Socio-economic Classification: (Rebased on the SOC2010) User Manual. Basingstoke: Palgrave Macmillan.

Oswalt, Philipp (Ed.) 2005: Shrinking Cities. Volume 1: International Research. Ostfildern-Ruit: Hatje Cantz.

Parkinson, Michael 2016: UK city regions: policies, performance and prospects. In: Town Planning Review 87,6: 629-653 [doi: 10.3828/tpr.2016.42a].

Parkinson, Michael et al. 2006: State of the English Cities: A Research Study. 2 Vols. London: ODPM.

Parr, John B. 2012: The Spatial-Cycle Model (SCM) revisited. In: Regional Studies 46,2: 217-228 [doi: 10.1080/00343404.2011.558895].

Porter, Libby; Shaw, Kate 2009: Whose Urban Renaissance? An international comparison of urban regeneration strategies. Abingdon: Routledge.

Rae, Alasdair 2013: English urban policy and the return to the city: A decade of growth, 2001-2011. In: Cities 32: 94-101 [doi: 10.1016/j.cities.2013.03.012].

Rérat, Patrick 2012: The new demographic growth of cities: the case of reurbanisation in Switzerland. In: Urban Studies 49,5: 1107-1125 [doi: 10.1177/0042098011408935].

Rink, Dieter et al. 2012: From Long-Term Shrinkage to Re-Growth? The Urban Development Trajectories of Liverpool and Leipzig. In: Built Environment 38,2: 162-178 [doi: 10.2148/benv.38.2.162].

Salet, Willem et al. 2015: Planning for the new European metropolis: functions, politics, and symbols/Metropolitan regions: functional relations between the core and the periphery/Business investment decisions and spatial planning policy/Metropolitan challenges, political responsibilities/Spatial imaginaries, urban dynamics and political community/Capacity-building in the city region: creating common spaces/Which challenges for today's European metropolitan spaces? In: Planning Theory and Practice 16,2: 251-275 [doi: 10.1080/14649357.2015.1021574]. 
Savini, Federico 2014: What Happens to the Urban Periphery? The Political Tensions of Postindustrial Redevelopment in Milan. In: Urban Affairs Review 50,2: 180-205 [doi: 10.1177/1078087413495809].

Scott, Allen J. 2008: Social Economy of the Metropolis: Cognitive-Cultural Capitalism and the Global Resurgence of Cities. New York: Oxford University Press.

Siedentop, Stefan; Fina, Stefan 2012: Who Sprawls Most? Exploring the Patterns of Urban Growth across 26 European countries. In: Environment and Planning A 44,11: 2765-2784 [doi: 10.1068/a4580].

Simpson, Ludi 2007: Fixing the population: from census to population estimate. In: Environment and Planning A 39,5: 1045-1057 [doi: 10.1068/a38141].

Soja, Edward 2015: Accentuate The Regional. In: International Journal of Urban and Regional Research 39,2: 372-381 [doi: 10.1111/1468-2427.12176].

St Helens Council 2008: Sustainable Community Plan 2008-2018. St Helens: St Helens Council.

St Helens Council 2012: St. Helens Local Plan: Core Strategy. St Helens: St Helens Council.

St Helens Council 2015: Bold Forest Park Area Action Plan: Publication Draft Nov 2015. St Helens: St Helens Council.

St Helens Council 2016: St. Helens Local Plan 2018-2033: Preferred Options. St Helens: St Helens Council.

Sturzaker, John; Mell, lan 2016: Green Belts: Past; Present; Future? Abingdon: Routledge.

Taylor, Nige/ 1998: Urban Planning Theory since 1945. London: Sage.

Turok, Ivan; Mykhnenko, Vlad 2007: The trajectories of European cities, 1960-2005. In: Cities 24,3: 165-182 [doi: 10.1016/j.cities.2007.01.007].

Urban Task Force 1999: Towards an Urban Renaissance. London: Spon.

Van den Berg, Leo et al. 1982: Urban Europe: A Study of Growth and Decline. Oxford: Pergamon.

Van Gent, Wouter; Musterd, Sako 2016: Class, migrants, and the European city: spatial impacts of structural changes in early twenty-first century Amsterdam. In: Journal of Ethnic and Migration Studies 42,6: 893-912 [doi: 10.1080/1369183X.2015.1126092].

Wiechmann, Thorsten; Pallagst, Karina M. 2012: Urban shrinkage in Germany and the USA: A Comparison of Transformation Patterns and Local Strategies. In International Journal of Urban and Regional Research 36,2: 261-280 [doi: 10.1111/j.14682427.2011.01095.x].

Williams-Ellis, Clough 1928: England and the Octopus. London: Geoffrey Bles.

Wray, lan 2011: In search of strategic sites: North West England, 1990-2010. In: Town Planning Review 82,3: i-ix [doi: 10.3828/tpr.2011.21]. 
244 - Sebastian Dembski, Andreas Schulze Bäing, Olivier Sykes

Dr. Sebastian Dembski $(\bowtie)$, Dr. Olivier Sykes. Department of Geography and Planning, University of Liverpool. United Kingdom. E-mail: sebastian.dembski@liverpool.ac.uk, olivier.sykes@liverpool.ac.uk

URL: https://www.liverpool.ac.uk/environmental-sciences/staff/sebastian-dembski/ https://www.liverpool.ac.uk/environmental-sciences/staff/olivier-sykes/

Dr. Andreas Schulze Bäing. School of Environment, Education and Development, The University of Manchester. United Kingdom.

E-mail: andreas.schulze.baing@manchester.ac.uk

URL: http://www.manchester.ac.uk/research/Andreas.Schulze.Baing/ 


\section{Comparative Population Studies}

wWW.comparativepopulationstudies.de

ISSN: 1869-8980 (Print) - 1869-8999 (Internet)

\section{Published by}

Prof. Dr. Norbert F. Schneider

Federal Institute for Population Research D-65180 Wiesbaden / Germany

\section{(cc) BY-SA}

2017

\section{Managing Editor}

Frank Swiaczny

\section{Assistant Managing Editor}

Katrin Schiefer

\section{Copy Editor}

(Selected Articles in German)

Dr. Evelyn Grünheid

\section{Layout}

Beatriz Feiler-Fuchs

E-mail: cpos@bib.bund.de

\section{Scientific Advisory Board}

Paul Gans (Mannheim)

Karsten Hank (Cologne)

Johannes Huinink (Bremen)

Michaela Kreyenfeld (Rostock)

Marc Luy (Vienna)

Notburga Ott (Bochum)

Peter Preisendörfer (Mainz)

Nikola Sander (Groningen)

Zsolt Spéder (Budapest)

\section{Board of Reviewers}

Martin Abraham (Erlangen)

Laura Bernardi (Lausanne)

Hansjörg Bucher (Bonn)

Claudia Diehl (Konstanz)

Andreas Diekmann (Zurich)

Gabriele Doblhammer-Reiter (Rostock)

Jürgen Dorbritz (Wiesbaden)

Anette Eva Fasang (Berlin)

E.-Jürgen Flöthmann (Bielefeld)

Alexia Fürnkranz-Prskawetz (Vienna)

Beat Fux (Salzburg)

Joshua Goldstein (Berkeley)

Sonja Haug (Regensburg)

Hill Kulu (Liverpool)

Aart C. Liefbroer (The Hague)

Kurt Lüscher (Konstanz)

Emma Lundholm (Umeå)

Nadja Milewski (Rostock)

Dimiter Philipov (Vienna)

Roland Rau (Rostock)

Tomáš Sobotka (Vienna)

Jeroen Spijker (Barcelona)

Olivier Thévenon (Paris)

Helga de Valk (Brussels)

Heike Trappe (Rostock)

Michael Wagner (Cologne) 